\title{
The Environment and Guidelines of Administration to Develop Innovators Among Secondary Science Teachers at Saint Gabriel's Foundation, Thailand
}

\author{
${ }^{1}$ Phongtorn Kaewyongphang, ${ }^{2}$ Monnapat Manokarn, ${ }^{3}$ Yongyouth Yaboonthong \\ ${ }^{1,2,3}$ Faculty of Education Chiang Mai University, Thailand \\ Email:1phongtorn_ka@cmu.ac.th, ${ }^{2}$ monnapat.m@cmu.ac.th, ${ }^{3}$ yongyouth.y@cmu.ac.th
}

\begin{abstract}
The purpose of this research was to study the environment and guidelines of administration to develop innovators among secondary science teachers at Saint Gabriel's Foundation, Thailand. Quantitative and qualitative researches were used and research tools were questionnaires and open-ended questions. The data has been gathered from 11 secondary school directors, 110 staff at the management level and 149 secondary science teachers at Saint Gabriel's Foundation, Thailand in the academic year 2020. The quantitative data was analyzed by descriptive statistic, whereas content analysis was used to analyze qualitative data. Results indicated that strengths of the environment to develop innovators among secondary science teachers were school systems, management styles of directors, creativity skills of teachers, critical thinking skills, information technology and communication skills, share value, participatory work and teamwork. The weaknesses were school strategies and structures obstructing innovator development of teachers, lack of innovative process knowledge, and entrepreneurial and financial skills. The opportunities were technological advancement, social and political conditions that affected the development of innovators. The threat was the slowdown of economic conditions of students' families and communities. According to the study, the five guidelines for the development of innovators among secondary science teachers, developing school strategies, developing school structure, promoting teacher innovator development, learning and coaching, and networking were found.
\end{abstract}

Keywords

Innovator Teacher, Innovator, Educational Administration

Article Received: 10 August 2020, Revised: 25 October 2020, Accepted: 18 November 2020

\section{Introduction}

Innovation is an important factor of the determinant of competitiveness and national progress. Many countries have adopted national strategic roadmaps to foster innovation and enhance its economic impact [1].

Thai society has been changed to knowledge-based learning and innovations. The promotion of new policy of Thailand 4.0 which is consistent with the 12th National Economics and Social Development Plan (2017-2021) [2] focuses on the urgent necessity of using science knowledge, technology, and innovations which is less operated in the present to enhance the competitive ability, the value chain of agricultural production, industries, and services. Nowadays, Thailand encounters an issue of quality on all sides such as people, educations, public services and public services. Moreover, the rate of inequality in Thai society is high. One of the immense issues which is focused during the 12th National Economics and Social Development to raise the potential of the country is the development of innovations and driving the innovations to develop every dimension of the country.

The national Scheme of Thai Education (2017-2036) [3] is the master plan for institutions related to education to apply it as the framework for educational development. The vision "All Thai are able to access to quality education and lifelong learning, live happily consistently with sufficiency economy philosophy and the 21 st century world changes" is valued. To achieve the visions and aims of the educational management, 2 goals have been set in the National Scheme of Thai Education. The first goal is Learner Aspiration aiming to develop every learner with the 21th century characteristics and learning skills (3Rs 8Cs), and 5
Aspirations. The 3Rs $8 \mathrm{Cs}$ consists of $3 \mathrm{Rs}$ which are reading, writing, arithmetic and $8 \mathrm{Cs}$ which are critical thinking and problem solving, creativity and innovation, cross - cultural understanding, collaboration teamwork and leadership, communications information and media literacy, computing and ICT literacy, career and learning skills, and compassion. The second goal is 5 Aspirations comprising access, equity, quality, efficiency, and relevancy. Hence, institutions and teachers have to be directly relevant to learning management to achieve the objectives of the educational management.

Teachers are the professional personnel who are responsible for teaching and support learners' learning by using various methodologies in public and private schools [4]. They play important roles in educational management since their duties are to manage the learning process, train, and teach students to have knowledge, specific skills, and ability to encounter various situations. Therefore, teachers are essential personnel for Thai educational development [5].

The progression of technology leads to shift of previous to the modern learning model which is one-way learning, teachers are the only resource transferring information to students, to self-learning which students are able to learn by themselves. For this reason, it is necessary for teachers to improve their skills to be consistent with the changes [6]. According to Sinlarat [7], presented the education 4.0 which develop learners to produce products that clearly reflect new idea and new system called "innovation." Leading learners to enable to create the innovation, development of both teacher and students' skill is indispensable. Furthermore, skills, knowledge, understanding about innovation process, needed-skills for creating innovations, and innovator are necessary for teacher improvement which improve them to 
be able to lead students to be innovators.

The Saint Gabriel's Foundation of Thailand [8], the private organization, is managed by Roman Catholic priests called Montfort Brothers of St. Gabriel. The organization was founded in 1715 by Saint Louis-Marie Grignion de Montfort in France. Members of Montfort Brothers of St. Gabriel work around the world; in Thailand, they have been worked in the first institution Assumption College since 20th October, 1901 to the present. Nowadays, there are institutions located in the central, northern, east and north east of Thailand under the management of St. Gabriel's Foundation; 14 institutions providing the basic education, 2 institutions for vocational school, and 1 university. The school management has to be changeable due to the world changing and educational policy; school directors value teacher innovator development to organize classrooms and prepare students to the international world. The results of the study are valuable for teaching professional development and affect student quality which is consistent to educational revolution policy. Moreover, the basic education school administration can profitably apply the results as guidelines for the school in the future.

\section{Research Objectives}

To study current and desirable conditions of administration to develop innovators among secondary science teachers at Saint Gabriel's Foundation, Thailand.

\section{Research Methods}

In the research, a mixed-method which consisted of qualitative and quantitative researches was used to study the current and desirable conditions of administration to develop innovators among secondary science teachers at Saint Gabriel's Foundation, Thailand. The data collection was divided into 2 periods; the first period is the qualitative data collection which is not only the conceptual framework of the research, but also basic data for quantitative data collection in the second period. The data has been collected from 11 secondary school directors, 110 staff at the management level and 149 secondary science teachers at St. Gabriel's Foundation, Thailand in the academic year 2020. Apart from data collection, in data analysis, data from the questionnaires was analyzed following these steps. The first step was to analyze background information of the respondents by using descriptive statistic to enumerate frequency and calculate percentage. The second step was to analyze the current and desirable conditions of administration to develop innovators among secondary science teachers at Saint Gabriel's Foundation, Thailand by using SPSS program for windows to find the average $(\bar{x})$ and standard deviation (S.D.). Both overview and classified environment which were inner and outer environments were analyzed. Next, the technique Modified Priority Need Index (PNImodified) was used to analyze the data from the second part of questionnaires to find S-W-O-T and identify the necessary requirement from the $\mathrm{PNI}_{\text {modified }}$ formula as presented [9].
$P N I_{\text {modified }}=\frac{I-D}{D}$

$P N I_{\text {modified }}$ is Modified Priority Need Index

I is the desirable conditions is the current conditions

Research process of this research has developed into 4 steps consisted of literature review, research design and instrument construction, data collection and data analysis, and to discussion and conclusion. Steps were shown in Fig. 1.

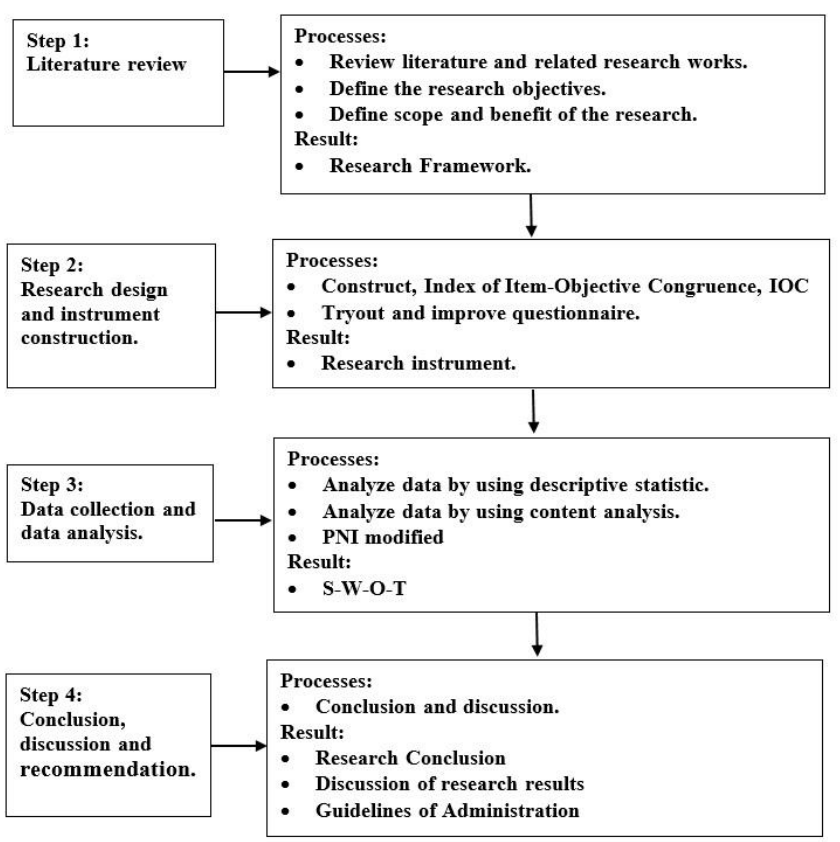

Fig.1 Research process for study the environment to develop innovators among secondary science teachers.

\section{Results}

1. The analysis of content validity, reliability of the questionnaire. The findings showed that the values of construct, the questionnaire was checked by 5 experts. It found that Index of Item-Objective Congruence (IOC) of all items was above 0.600. Therefore, the questionnaire was appropriate to use. The Cronbach's alpha statistic for reliability analysis was proved for the questionnaire with the result of 0.970 in current condition and 0.980 in desirable condition. This indicated that there was acceptable reliability.

2. The results of the analysis of the average $(\bar{x})$ and standard deviation (S.D.) of environment to develop innovators among secondary science teachers at Saint Gabriel's Foundation, Thailand are shown in Table I and the recommendations of the guidelines of administration to develop innovators among secondary science teachers at Saint Gabriel's Foundation, Thailand are presented in the Table II. 
Table I. The average, standard deviation, and $\mathrm{PNI}_{\text {modified }}$ on the environment to develop innovators among secondary science teachers at Saint Gabriel's Foundation.

\begin{tabular}{|c|c|c|c|c|c|c|}
\hline & \multirow{2}{*}{$\begin{array}{l}\text { Environment } \\
\text { to Develop } \\
\text { Innovators } \\
\text { Among } \\
\text { Secondary } \\
\text { Science } \\
\text { Teachers }\end{array}$} & \multicolumn{2}{|c|}{$\begin{array}{l}\text { Current } \\
\text { condition }\end{array}$} & \multicolumn{2}{|c|}{$\begin{array}{l}\text { Desirable } \\
\text { condition }\end{array}$} & \multirow{2}{*}{$\begin{array}{l}\text { PNI } \\
\text { modified }\end{array}$} \\
\hline & & $\bar{x}$ & S.D. & $\bar{x}$ & S.D. & \\
\hline 1. & Strategy & 3.69 & 0.61 & 4.46 & 0.47 & 0.207 \\
\hline 2. & Structure & 3.63 & 0.66 & 4.46 & 0.49 & 0.229 \\
\hline 3. & System & 3.67 & 0.65 & 4.50 & 0.51 & 0.226 \\
\hline 4. & Style & 3.90 & 0.63 & 4.60 & 0.47 & 0.178 \\
\hline 5. & Staff & 3.64 & 0.65 & 4.51 & 0.52 & 0.240 \\
\hline 6. & Skills & 3.71 & 0.55 & 4.58 & 0.46 & 0.235 \\
\hline 7. & Share Value & 3.84 & 0.60 & 4.61 & 0.47 & 0.200 \\
\hline 8. & $\begin{array}{l}\text { Social } \\
\text { Conditions }\end{array}$ & 3.62 & 0.63 & 4.48 & 0.50 & 0.236 \\
\hline 9. & $\begin{array}{l}\text { Technology } \\
\text { Conditions }\end{array}$ & 4.06 & 0.58 & 4.61 & 0.461 & 0.136 \\
\hline 10. & $\begin{array}{l}\text { Economic } \\
\text { Conditions }\end{array}$ & 3.55 & 0.61 & 4.32 & 0.54 & 0.219 \\
\hline 11. & $\begin{array}{l}\text { Political } \\
\text { Conditions }\end{array}$ & 3.61 & 0.65 & 4.43 & 0.58 & 0.227 \\
\hline
\end{tabular}

Table II. The Recommendations of the guidelines of administration to develop innovators among secondary science teachers at Saint Gabriel's Foundation, Thailand.

\begin{tabular}{|l|l|l|}
\hline & $\begin{array}{l}\text { The guidelines of administration to } \\
\text { develop innovators among secondary } \\
\text { science teachers }\end{array}$ & Frequency \\
\hline 1. & $\begin{array}{l}\text { Establish strategies to develop innovators } \\
\text { of teachers and clearly set Key } \\
\text { Performance Indicators. }\end{array}$ & $n=76$ \\
\hline 2. & $\begin{array}{l}\text { Add more agencies of the innovator } \\
\text { development of teachers and students in } \\
\text { the management structure. }\end{array}$ & $n=75$ \\
\hline 3. & $\begin{array}{l}\text { Identify the innovator development of } \\
\text { teachers in teachers' job descriptions. }\end{array}$ & $n=87$ \\
\hline 4. & $\begin{array}{l}\text { Set teachers' innovator development plans } \\
\text { and put it into action with constant } \\
\text { monitoring and evaluating. }\end{array}$ & $\mathrm{n}=65$ \\
\hline 5. & $\begin{array}{l}\text { Encourage and reinforce teachers to } \\
\text { develop innovator. }\end{array}$ & $\mathrm{n}=82$ \\
\hline 6. & $\begin{array}{l}\text { Select teachers to develop innovators and } \\
\text { skills according to their aptitude. }\end{array}$ & $\mathrm{n}=73$ \\
\hline 7. & $\begin{array}{l}\text { Provide training and knowledge for } \\
\text { teachers to develop innovator. }\end{array}$ & $\mathrm{n}=95$ \\
\hline 8. & $\begin{array}{l}\text { Appropriately allocate time and necessary } \\
\text { resources for the innovator development } \\
\text { of teachers. }\end{array}$ & $\mathrm{n}=70$ \\
\hline 9. & $\begin{array}{l}\text { Create teamwork culture for teachers to } \\
\text { exchange knowledge of learning } \\
\text { management and innovation development. }\end{array}$ & $\mathrm{n}=73$ \\
\hline
\end{tabular}

\section{Discussions}

The study of the current and desirable conditions of administration to develop innovators among secondary science teachers at Saint Gabriel's Foundation, Thailand had interesting discussed issues as shown below.

1. The results of the study of environment of administration to develop innovators among secondary science teachers at Saint Gabriel's Foundation, Thailand which were from 270 returned questionnaires found the strengths, weaknesses, opportunities, and threats are as follows,

1.1 Inner environment of institutions which is divided into 7 parts [10] is as follows,

\section{S1. Strategy}

The strengths are setting strategies, visions, missions, objectives, major strategies, minor strategies, establishing action plans and projects of school which encourage developmental innovators of teachers. However, the weakness is the evaluations and conclusions of projects, and reviewing the strategies which obstruct developmental innovators of teachers.

\section{S2. Structure}

The strengths of structure of inner environment in institutions are curriculum structure of the school, appointment order of the activity committee and establishing duties and responsibilities of teachers which encourage the developmental innovators of teachers provided in the school. In contrast, there are weaknesses impeded the innovator development which are setting agencies followed the structure and inappropriate allocating time discouraging the developmental innovators.

\section{S3. System}

The management system with specific roles, duties, and frameworks, supporting of budges and technology to develop innovators of teachers are the strengths, whereas lack of system which reinforce teachers to develop the innovators is the weakness. Moreover, teachers are not involved in the planning, framing, and organizing the teaching schedule is a big problem as well as the development of innovators is not a part of the consideration of promotion and advancement.

\section{S4. Style}

The strengths of the inner environment style of institutions consist of the style of school directors which encourage teachers to apply and create innovations for learning management, the supervising, and monitoring of the innovator development valued by school directors. Having less opportunities to share ideas of innovator development and creating various lesson plans of teachers are the weaknesses. Besides, the inadequate team-based learning and innovator development adversely led to bad effects.

\section{S5. Staff}

The evaluation plan of teacher development project, effective applying the teacher development project, and the constant self-improvement of teachers about innovations are strengths. Furthermore, the teaching schedules which are 
appropriate with the ability of teachers is the major strength. The weaknesses of the staff found are lack of an analysis of needs for innovator development among teachers, the teacher selection for the developmental inventor process, designing, setting developmental activity of innovators, and the inadequacy of teachers who specialize about innovations.

\section{S6. Skills}

The strengths are teachers are able to initiate and create new things. Critical thinking, idea connection and integrated management, systematic learning and management, leadership, effective communication are the great advantages. However, lack of innovative design to create new innovations, entrepreneurial skills, marketing skills, cost management, including income management are weaknesses. Besides, the valuation of creating innovations for learning management, establishing connections between outer agencies, team-based learning, creating innovation competition, lack of time for studying and developing innovations, and integrating innovation process with learning management are disadvantages.

\section{S7. Share Value}

The strengths are teachers' sacrifices for development, and enthusiasm to cooperate in potential development provided from school. Moreover, being responsible and altruist are the strengths. The weaknesses are school do not review the corporate performance between each department and the school to evaluate the activities. In addition to lack of understanding about innovator development of teachers for learning management, teachers hardly work in team and focus on innovation also use less innovations for the society.

1.2 Outer environment are divided into 4 parts as shown below,

\section{Social Conditions}

Memorandum of Understanding (MOU) of teacher development between schools and outer agencies, the support and help of teacher trainings from network schools, and the learning resources which support teacher to develop the innovators are opportunities. On the contrary, lack of support from public and private agencies, ineffective local cultures to the innovator development of teachers are threats. Moreover, domestic child birth rates affect innovations of teachers.

\section{Technology Conditions}

The essential role of technology to develop creativity, the progression and variety of technology which encourage the innovator development among teachers are the opportunities. Nonetheless, the threats which are technology of outer learning resources obstructing the innovator development, lack of technological systems to consistently develop teacher innovators are found. Furthermore, technology used as media cannot decrease time and cost of teacher innovators development.

\section{Economic Conditions}

The opportunities are the supported budges from external funding sources for innovator development, the competitor schools affect the innovator development, also the overall economic conditions. The threats are economic conditions of parents, families, and communities that affect the innovator development.

\section{Political Conditions}

Policies of innovator development from an original affiliation, the political changes which stimulate the innovator development are opportunities. However, threats are the educational and the innovator development policies of government, the standard of the innovator development among science teachers set by the professional associations. 2. According to the data collection, the results of the guidelines of administration to develop innovators among secondary science teachers at Saint Gabriel's Foundation, Thailand were discovered and the researcher divided the guidelines of administration to develop innovators among secondary science teachers into 5 guidelines as shown below.

\section{Developing School Strategies}

The implementation of developing school strategies, setting the Key Performance Indicators (KPI), and establishing teacher innovator development plan including the continuous monitor and evaluation were agreeable with the strategic plan of Saint Gabriel's Foundation, Thailand [8] which focused on the effective encouragement and development of Brothers and teachers, knowledgeable, skilled, and be able to effectively work according to the professional standards.

\section{Developing school structure}

Adding agencies which develop innovators of teachers and students in the organizational structure of the school was consistent to the strategic plan of Saint Gabriel's Foundation, Thailand [8] which intently developed human resources of schools in the foundation to be systematic and competent.

\section{Promoting of teacher innovator development}

Encouragement and reinforcement of innovator development of teachers, identifying the innovator development of teachers in teachers' job descriptions, teacher selections to develop innovators and skills according to the aptitude, providing appropriate time and necessary resources for the innovator development of teachers were agreeable with the recommendation of Tangjuang [11]. The consideration of self-improvement which organized the communicative habits for working space, expressing admiration to teacher who improve themselves by providing them a chance to present their work, facilitating or providing factors encouraging the self-improvement of teachers were mentioned in the recommendations. 


\section{Learning and coaching}

Providing training and knowledge in innovator development of teachers assented to the study of Yosyingyong [12]. According to the study, the personnel was a person who created innovations. Thus, the organization had to provide education or training for the personnel to be knowledgeable and be able to connect it with creativity and entrepreneurs to use innovations. Moreover, Wongthongdee [13] said that the individual development could be done in various ways such as training, providing educational management for personnel, the development through working experiences, and the development through the interaction with colleagues.

\section{Networking}

Creating teamwork culture for teachers to exchange learning management knowledge and innovation development was agreeable with the education of Office of the Education Council [14]. The development of Professional Learning Community (PLC) of teachers and teacher network was one way to support teachers, administrators and educational personnel. They could develop and change themselves to organize effective learning management which responded to different educational contexts. As reported by Dyer [15], creating the efficient idea network helped innovators create processes, products, and services which were advantages: similarly, the study of Widodo and Gustari [16] reported that Knowledge Management, creativity, and Organizational Citizenship Behavior were essential antecedents for innovative behavior.

\section{Acknowledgements}

We would like to express our deepest appreciation to Graduate School Chiang Mai University for the research grant, Asst.Prof.Dr. Monnapat Manokarn, and Asst.Prof.Dr. Yongyouth Yaboonthong, advisors who gave invaluable advice and contribution to this research. Moreover, special thanks to the Montfort Brothers of Saint Gabriel, Thailand including teachers of all levels, the cooperative and facilitative supporters

\section{References}

[1] OECD, "Innovating Education and Educating for Innovation: The Power of Digital Technologies and Skills", Paris: OECD Publishing, 2016.

[2] Office of the Prime Minister, "The Twelfth National Economic and Social Development Plan (2017-2021)", Office of the National Economic and Social Development Board, Bangkok, Thailand, 2017.
[3] Office of the Education Council, "The National Education Plan (2017-2036)", Ministry of Education, Bangkok: Prig Wan Graphic, 2017.

[4] The Royal Thai Government, "The National Education Act B.E. 2542 (1999)", The Royal Thai Government Gazette, 116 (part 74A, 19 August), 1-23, 1999.

[5] Office of the Education Council, "The Education Report: The status Teacher Preparation and Development in Thailand", Bangkok: Prig Wan Graphic, 2013.

[6] P. Dechakup, \& P. Kangkan, "Teacher competency and teachers' guidelines in changing society", Bangkok: Office of the Education Council, 2008.

[7] P. Sinlarat, "Education 4.0: More Than Education", Bangkok: Chulalongkorn University Press, 2016.

[8] The Saint Gabriel Foundation of Thailand, "Six Year Strategic Plan of the Saint Gabriel Foundation of Thailand, 20162021", Bangkok: Plan Printing Publisher Limited, 2016.

[9] S. Wongwanich, "Needs Assessment Research", Bangkok: Chulalongkorn University Press, 2015.

[10] McKinsey Quarterly, "Enduring Ideas: The 7-S Framework", McKinsey \& Company, http://www.mckinsey.com/insights/strateg y/enduring_ideas_the_7-s_framework, 2008 .

[11] P. Tangchuang, "The Models of Educational Personnel Competency Development", Bangkok: Duang Kamol Publishing Company, 2011.

[12] K. Yosyingyong, "Innovative Organization: Concept \& Process", Bangkok: Chulalongkorn University Press, 2009.

[13] S. Wongthongdee, "Human Resources Development", Bangkok: Chulalongkorn University Press, 2016. 
[14] Office of the Education Council, "Lessons from educational institutions in teacher development through professional learning communities (PLC) to the development of learners according to national educational standards", Bangkok: Office of the Education Council, 2020.

[15] Dyer, Jeffrey H., Hal B. Gregersen, and Clayton M. Christensen, "The Innovator's DNA: Mastering the Five Skills of Disruptive Innovators", Boston, MA: Harvard Business Press, 2011.

[16] W. Widodo, Irvandi Gustari, "Teacher's Innovative Behavior in Indonesian School: The Role of Knowledge Management, Creativity and OCB," Universal Journal of Educational Research, Vol. 8, No. 10, pp. 4784 - 4791, 2020. DOI: 10.13189/ujer.2020.081050 